\title{
Faldellines del Período Formativo en el Norte Grande: Un ensayo acerca de la historia de su construcción visual
}

INDIRA MontT S. ${ }^{1}$

RESUMEN

\begin{abstract}
A partir de investigaciones precedentes ${ }^{2}$ se caracterizó el atuendo presentado por las pinturas antropomorfas de la cuenca alta del río Salado, principal tributario del Loa, siendo el faldellín la única vestimenta textil representada. Desde esta sistematización, con claros correlatos cronológicos, se abordan las figuras con faldellines presentes en sitios de Pisagua, Quebradas Aroma y Guatacondo y San Pedro de Atacama. Este es un ejercicio que intenta, desde la mirada iconológica y el conocimiento arqueológico, una aproximación a ciertas soluciones formales en el ámbito de la representación plana, sus tendencias temporales, además de profundizar en la comprensión interpretativa sobre los aspectos sociales y culturales contenidos en las representaciones que exhibe esta prenda.
\end{abstract}

Palabras claves: Norte Grande de Chile - representación - iconología - faldellines - arte rupestre - textiles.

\section{ABSTRACT}

On the basis of previous research, this paper characterizes the attire worn by the anthropomorphic paintings located in the high basin sites of the river Salado (the main tributary of the Loa), the fringed pubiccovering being the only piece of clothing that is represented. Learning on this systematization and its clear chronological correlates, we considered figures from sites in Pisagua, the gorges of Aroma and Guatacondo and San Pedro de Atacama that also have fringed pubic coverings. This exercise is an approximation to certain formal solutions in the field of flat representations from an iconological perspective based on archaeological evidence and its temporal tendencies, in order to deepen our understanding of the social and cultural aspects evidenced by the representations exhibiting this garment.

Key Words: Northern Chile - representation - iconology - fringed pubic covering - rock art - textiles.

Recibido: enero 2003. Manuscrito revisado aceptado: Julio 2003.

1 Instituto de Investigaciones Arqueológicas y Museo R. P. Gustavo Le Paige s. j. de la Universidad Católica del Norte, Casilla 17, Correo San Pedro de Atacama, II Región. Email: imontt@ucn.cl o indira1210@yahoo.com

2 Proyecto FONDECYT 1980200.

\section{Adiós a la inocencia}

El presente trabajo forma parte de la línea de investigación que tuvo como propósito hacer un seguimiento de los elementos de atuendo que presentan las figuras antropomorfas en el arte rupestre de la Subregión de río Salado (Montt, en prensa), los que muestran una persistencia desde el Período Formativo Temprano (ca. 1400 AC-100 DC) hasta el Período Intermedio Tardío (900-1450 DC). En términos metodológicos se registraron los atributos de cada una de las representaciones de objetos, los que, al ser analizados, permitieron definir diversos tipos de faldellines, tocados y objetos en las manos.

Sin embargo, toda esta labor fue desarrollada de una manera que podría llamarse intuitiva, en cierto estado de ingenuidad teórica. El presente ensayo intenta, con posterioridad, revertir el proceso de interpretación de la imagen antropomorfa con faldellín, convirtiendo lo que fue sólo análisis en un discurso reflexivo que fundamente las perspectivas asumidas, el paso a paso analítico y la lógica interpretativa, organizando un proceso que, lejos de quedar resuelto, aquí sólo comienza. El modelo de análisis generado a partir del registro parietal del río Salado es ahora, en este trabajo, ensayado sobre representaciones allende la localidad (Figura 1) generándose la discusión y los comentarios que se exponen.

\section{Nuevas visiones de viejas imágenes}

En la investigación arqueológica del desierto de Atacama ha habido un sinnúmero de trabajos que consideran los aspectos religiosos (Plagemann 1906; Strube 1926), mágicos (Ryden 1944), cúlticos (Mostny y Kunsemüller 1960), mítico o mítico-rituales (Berenguer y Martínez 1986; Berenguer 1995, 1996, 1999; Chacama y Espinoza 1997) y ceremoniales (Berenguer 1996; Dransart 1997) del arte rupestre. Al revisar estos antecedentes, es posible notar un esfuerzo por parte de 


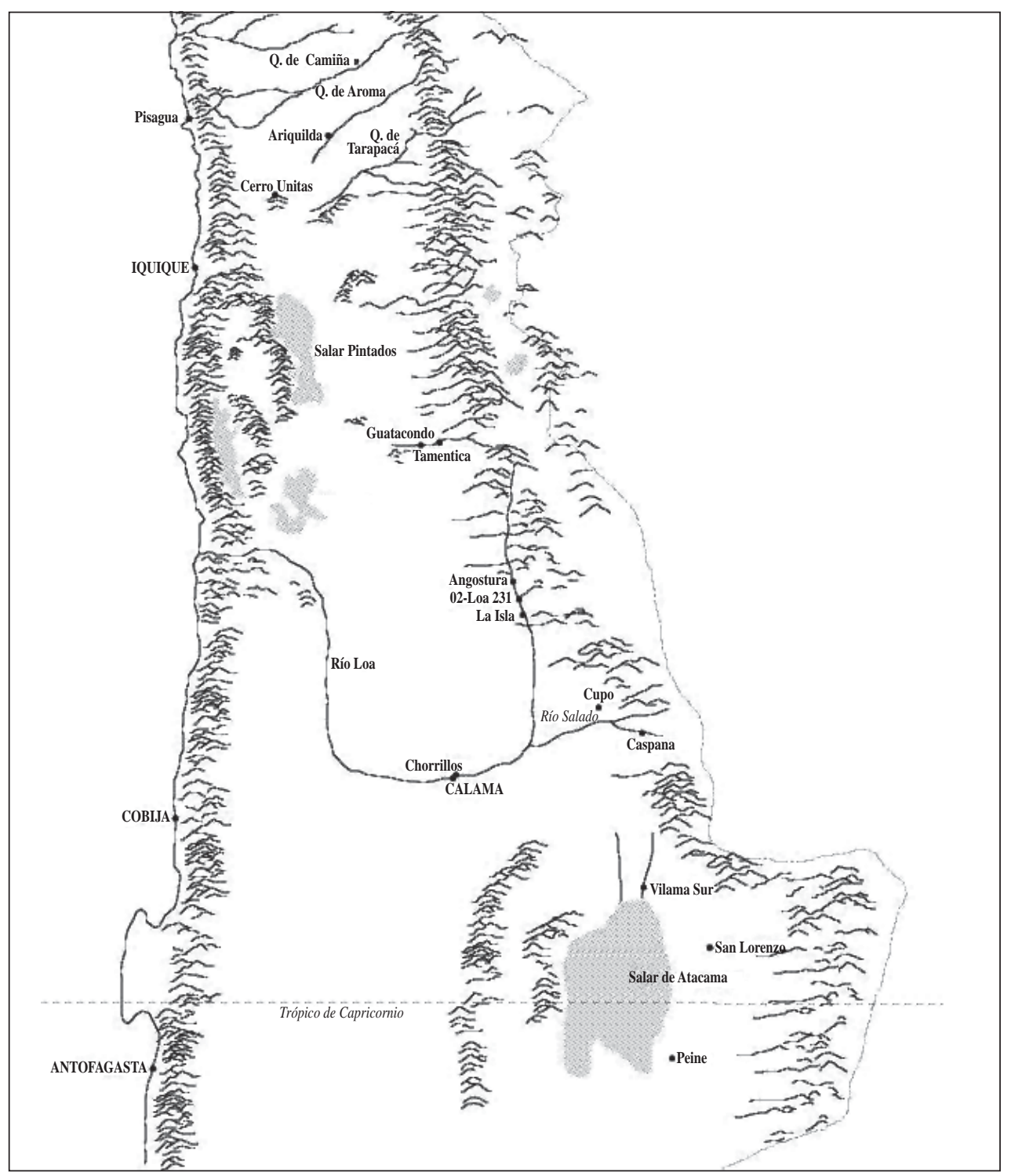

Figura 1. Mapa de la zona con los sitios mencionados en el texto.

los estudiosos de elaborar una interpretación de la imagen sobre la base de categorías o marcos explicativos que son ajenos a la propia representación y al modo en que esta se construye a sí misma, en un tiempo y un espacio. Si bien se nos vuelve escurridizo el acceso al contenido significativo y a las motivaciones individuales y sociales movilizadas por el artista al momento de plasmar su obra, la imagen está ahí ante nosotros como una huella, como un registro intocado, completo y silencioso, al cual podemos acceder una y otra vez; si hay algo que radicalmente distingue a la imagen rupestre es esta permanencia, la que no se ve amenazada por recolecciones, excavaciones ni pérdidas.

En este sentido, el argumento que adscribe las expresiones "artísticas" al sombrío rótulo de lo religioso, mágico, cúltico, ritual o ceremonial constituye, quizás, el escollo tautológico en que tropiezan muchos intentos de avance por parte de la disciplina arqueológica en el camino hacia un conocimiento de la imagen parietal. Sin desconocer que el arte rupestre seguramente debió ser depositario activo de algunas de estas funciones sociales, cabe preguntarse: ¿qué instancia material de la vida en 
el pasado no lo fue? La huidiza función de este tipo de expresiones radica en la dificultad de reconocer y definir ciertos indicadores -formales o contextuales- elocuentes en tal sentido. Asimismo, el campo de lo sobrenatural no sólo ha sustentado explicaciones relativas a la funcionalidad, sino también en lo que respecta al significado.

El planteamiento que se expone está basado en la siguiente premisa: la interpretación de la imagen es posible de ser realizada a partir del estudio sistemático de los elementos o atributos que la conforman, además de los contextos materiales, sociales e históricos que tejen su red de relaciones. Es de este modo, y no al revés, que se hace posible un acercamiento pertinente a los contenidos socioculturales que le son inherentes. Lo anterior se sustenta en la idea de un estudio de la imagen rupestre a partir de su contexto de producción y no su contexto de uso-función; junto con plantearse una renuncia al significado como prioridad, se aborda la imagen en sí misma, en una metodología que busca la definición de tendencias formales y la exploración de sus implicaciones temporales, espaciales y culturales.

Se pretende tan sólo explorar la historia de la construcción visual del faldellín reparando en su valor diagnóstico como indicador temporal relativo. El material visual será tratado e interpretado desde una perspectiva iconológica y de este modo relacionado con procesos sociales y económicos, intentando con esto aprehender un contenido significativo siempre fragmentario; además se tendrán en consideración los tres aspectos definidos por Raphael (1968: 210) en relación a la forma: forma como presencia inmediata o forma actual, forma significativa y forma efectiva. Por último, se intentará cotejar -sin ahondar en análisis, más que los posibles de establecer a simple vista- la información visual disponible en la bibliografía de ciertas áreas del Norte Grande, además de imágenes no publicadas a la fecha, con la tipología planteada para el río Salado.

\section{La perspectiva iconológica}

La iconología -o iconografía en un sentido más profundo- surge en la historia del arte al modo en que lo hacen los gabinetes de antigüedades en los albores de nuestra disciplina arqueológica. Pretendiendo erigirse como una "ciencia de las imágenes", tiene su origen en los manuales de símbolos, alegorías y personificaciones que proliferaron en Europa entre los siglos XVI y XVIII. Hoy, la iconología es considerada como una iconografía (eikón: imagen, y gráphein: descripción) que se vuelve interpretativa, de manera que las obras sean contempladas sin un entretenimiento en las formas, sino en el contenido. Aún en la segunda década del siglo XX la historia del arte estaba dominada por una preocupación obsesiva por las formas; este formalismo buscaba las propiedades estéticas de la obra de arte y aislaba deliberadamente el objeto de su contexto histórico y cultural (Castiñeiras 1998; Mason 1998).

En esta primacía de la "pura visibilidad" iconográfica hace su aparición el padre de la iconología, Aby Warburg (1866-1929), quien abrió las puertas del hasta entonces muy constreñido campo de la historia del arte. Este alemán trató de superar la parcialidad de la consideración artística formal, que admitía como algo absolutamente necesario, aproximándose a la realidad visual en distintos frentes: su ideal era una amplia ciencia de la cultura, en la que no debía haber fronteras para las diferentes disciplinas. A este método, basado en la iconografía, lo llamó iconología, nombre que apareció por primera vez en su obra en 1912. De hecho, a la iconología también se le llamó "Método Warburgiano" (Kulterman 1996), siendo ésta la herramienta que posibilitó el despertar del contenido en la investigación de la expresión artística. De este modo, la iconología se inició principalmente como:

"un problema de método, bastante circunscrito, que ocupó el centro de las investigaciones y las meditaciones de Aby Warburg, y sería retomado y resuelto de distintas maneras por sus continuadores: la utilización de los testimonios figurativos (pinturas) como fuentes históricas" (Ginzburg 1999: 39). ${ }^{3}$

\footnotetext{
3 Sin embargo, existe en Gombrich, según Ginzsburg, una instalada desconfianza hacia el intento de utilizar las obras de arte $y$, en general, los testimonios figurativos considerados desde el punto de vista del estilo, como una fuente para la reconstrucción histórica general, pese a lo cual la historia (la relación entre los fenómenos artísticos y la historia política, religiosa, social, de la mentalidad, etc.) expulsada silenciosamente por la puerta vuelve a entrar por la ventana (sensu Ginzburg 1999: 73) señalando con esto que este es un tema no resuelto a cabalidad en la obra de Gombrich.
} 
Posteriormente, Erwin Panofsky (1892-1968) continuó en sus investigaciones la tradición fundada por Warburg, intentando redescubrir las actitudes culturales que se esconden tras los objetos históricos, tanto si se trata de un texto como de una obra de arte. Sin duda lo más novedoso de Panofsky fue haber sabido ofrecer un método básico aplicable a distintos campos de la investigación histórica, no dejándose llevar por la mera visión de la obra de arte, sino buscando el porqué de ciertas imágenes y actitudes en relación con determinadas situaciones históricas de manera que las obras se contemplaran no sólo como imágenes, sino también como ideas (Castiñeiras 1998). El método definido por Panofsky para describir y analizar una obra considera tres niveles de significación de la obra de arte: 1) nivel preiconográfico: descripción de la representación; 2) nivel iconográfico: tema y 3) nivel iconológico: contextualización y significado. Estas tres lecturas sin aparente vinculación entre sí conforman, en realidad, aspectos de un mismo fenómeno, los que se fusionan en un proceso indisoluble constituyendo categorías diferenciadas por la necesidad de un mayor o menor acercamiento a la manifestación artística (Panofsky 1972). Aun sabiendo que el conocimiento de Panofsky iba en pos del significado de las obras, esta metodología puede ser adaptada a los intereses de esta investigación, considerándose en un nivel preiconográfico la descripción objetiva de los aspectos técnicos, formales y compositivos de las figuras antropomorfas, sus elementos de atuendo y los elementos asociados. Una segunda instancia de comprensión de las manifestaciones rupestres tratará a partir del nivel iconográfico de reunir todas las figuras en estudio para asimilar tanto las recurrencias como variabilidad de sus atributos, indagando en las relaciones y combinatoria, el contexto, de cada uno de los antropomorfos con atuendo. Por último, la integración de los aspectos figurativos con aquellos extrínsecos a la propia representación (potenciales referentes y sus contextos, aspectos cronológicos, distribucionales, culturales entre otros) constituirá el contenido que se planteará en un nivel iconológico.

También en la tradición de investigación iconológica fundada por Warburg se inscriben los notables trabajos de Ernst H. Gombrich (19092002). Su aporte, en gran medida centrado en el estudio de las facultades perceptivas del espectador, permite por primera vez adentrarse en los recursos plásticos desplegados por el artista, dando cuenta de aquellos aspectos que subyacen a lo visible, pero que son inteligibles a partir de la misma imagen.

El marco interpretativo a ser aplicado se sustenta fundamentalmente en los lineamientos teóricos y metodológicos planteados por Warburg, Panofsky y Gombrich. Del primero se rescata el valor del contenido, en contraposición con un estudio de la expresión artística cifrado sólo en sus cualidades formales. En este sentido, el valor asignado por Panofsky a la unidad de la obra de arte, en lo que a forma y contenido se refiere, se traduce en la implementación de un método que permitiera una aproximación paulatina y sistemática a las artes visuales, considerándolas como una parte más del universo de la cultura. Es el eminente Gombrich quien avanza hacia una aprehensión de la obra de arte al considerar la noobviedad de la representación lo que logra adentrándose en las complejas convenciones o "ilusiones" que el artista utiliza en su hacer visible la realidad, en desmedro de una observación directa de esta. La investigación que se propone observará en esta sospecha, la que se vuelve interesante al abordar obras que se deben a expresiones precedentes, introduciendo a la vez nuevas soluciones. Esto se logra, en palabras de Gombrich, a partir del esquema y corrección:

"La representación de la realidad sería imposible sin la intervención de un "esquema"; un esquema provisional, acaso muy rudimentario y hasta casual, que luego se irá modificando por medio del proceso, muy conocido por los psicólogos, de trial and error" (Ginzburg 1999: 68; cursiva en el original).

Es así como, sobre los contenidos teóricos expuestos, se intentará encarar la obra rupestre no como un acopio de mensajes visuales con un significado y una función que aún se nos escapa, sino como un medio efectivo de adentrarnos en un imaginario, el que hoy es aprehensible para la arqueología no sólo por lo que ve, sino también por lo que sabe.

\section{Líneas sobre un plano: El faldellín como elemento visual diagnóstico}

Desde la vertiente contextual en arqueología, e iconológica en la historia del arte, se expondrá en 
estas líneas un estado de la situación en torno a las evidencias de representaciones con faldellines publicadas para las zonas aledañas a la Subregión de río Salado, tomando como referencia el modelo de análisis generado a partir del estudio sistemático del atuendo en esta última zona. Serán abordadas imágenes provenientes de los sitios de Pisagua Cementerio "D" o Protonazca en la costa de Arica (Colección Uhle, MNHN) ${ }^{4}$; Tamentica (Mostny y Niemeyer 1983: 46), Ariquilda 1 (Chacama y Briones 1996: 47, Fig. 3) y Guatacondo (Mostny y Niemeyer 1983: 89) en las Quebradas Intermedias; La Isla (Berenguer et al. 1985: 93, Fig. 93) y 2-Loa-231 (Sinclaire 1997: 336, Fig. 11) en el Alto Loa; Chorrillos (Latcham 1938: 293; Berenguer 1981: 172; Sinclaire 1997: 333) en el Loa Medio; San Lorenzo-1 (Núñez et al. 1997: 309-310), Peine-1 (Núñez et al 1997: 311-312) y Salar de Atacama. ${ }^{6}$

En la investigación llevada a cabo por Montt (en prensa) en la Subregión de río Salado sin duda el elemento diagnóstico de mayor potencial cronológico fue el tipo de faldellín. Se logró determinar que un $26 \%$ de los motivos antropomorfos de su arte rupestre vestían esta prenda. A base de este registro y a través de un análisis sistemático, fueron definidos tres tipos de faldellín: un Faldellín Segmentado (Figura 2), un Faldellín Segmentado Continuo (Figura 3) y una Falda Continua (Figu-

4 Proyecto FONDECYT 1960169 "El hombre arcaico costero: Su biodiversidad y bioadaptación". Señala la Ficha de Registro MNHN (realizada el 3-12-91): $\mathrm{N}^{\circ}$ del Objeto: 2209/ Propietario: Museo Histórico/ Ubicación en Museo: caja 132, Museo Histórico/ Nombre del objeto o de la especie: bolsa/ Lugar de origen: Punta de Pichalo, cerca de Pisagua, I Región/ Material: Lana/ Dimensiones: diámetro aproximado $17 \mathrm{~cm}$, alto aproximado $22 \mathrm{~cm} /$ Fuente: Expedición a la costa norte de Chile, cementerio "d" arriba, VIX-13/ Grupo cultural o étnico: Agroalfarero Temprano (Protonazca)/ Conservación: Regular estado, presenta algunas roturas y faltantes.

5 Posible gracias al Proyecto FONDECYT 1000148: "Historia cultural y materialidad en la arqueología de los períodos Intermedio Tardío y Tardío de San Pedro de Atacama y su relación con la cuenca del Loa".

6 El faldellín presentado por Dransart (1997: 212) para el sitio Tulan-67 me parece, a partir de la ilustración, poco diagnóstico, por lo que no es considerado en esta discusión. Por otra parte, no se incluyeron las pinturas antropomorfas con faldellines del alero de Sirantur (Barthel et al. 1959), por haber conocido su existencia poco después de la entrega de este manuscrito.

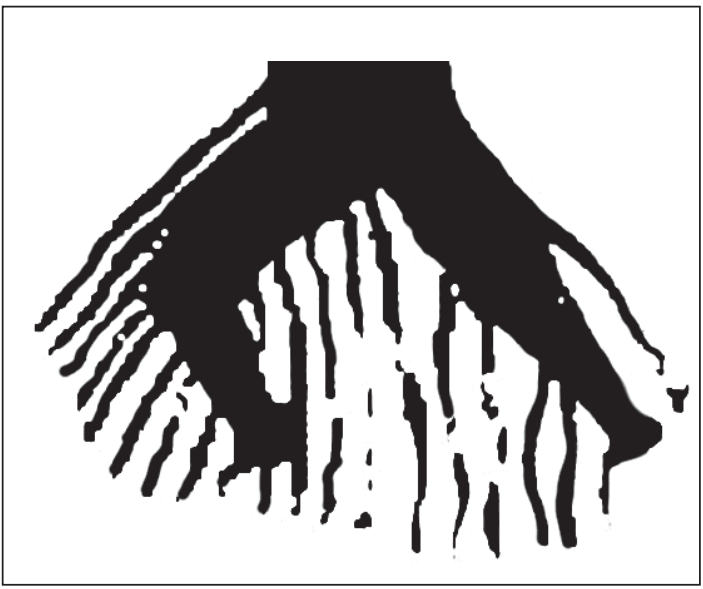

Figura 2. Faldellín Segmentado (archivo visual proyecto FONDECYT 1980200).

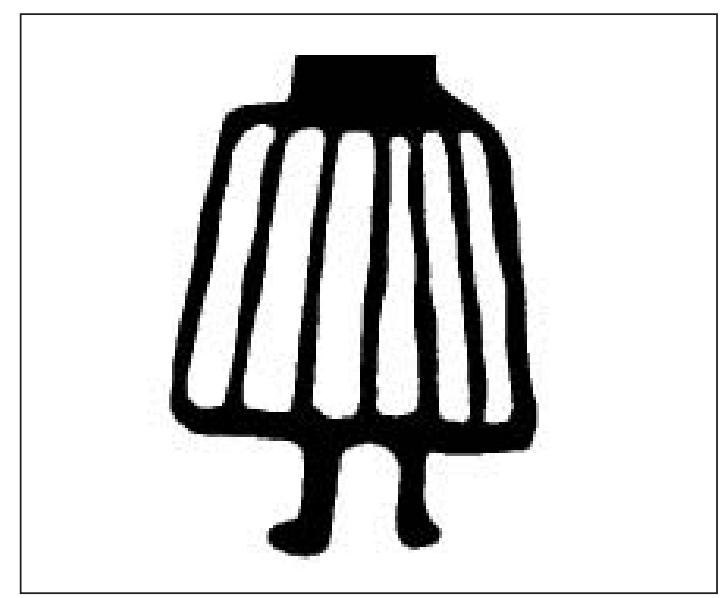

Figura 3. Faldellín Segmentado Continuo (archivo visual proyecto FONDECYT 1980200).

ra 4). ${ }^{7}$ Indirectamente, pudo ser reconocido un cuarto tipo denominado Faldellín Desdoblado.

Esta categorización no puede desentenderse de la relación que esta prenda establece con el cuerpo de las figuras. Es así como el Faldellín Tipo Segmentado, de alta representatividad en el temprano estilo Confluencia (1400 AC-100 DC), se construye en una transparencia que permite dar cuenta de la anatomicidad y el movimiento en las

\footnotetext{
Correspondientes a una línea horizontal de la que penden líneas verticales ("faldellín segmentado"), el mismo caso anterior pero con una línea perimetral o de borde ("faldellín segmentado continuo") y una línea trapezoidal ("faldellín continuo").
} 


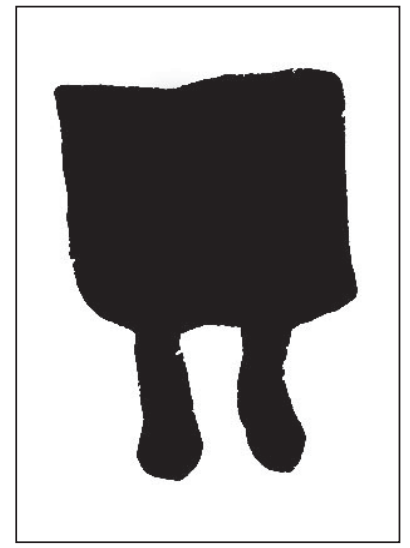

Figura 4. Falda Continua (archivo visual proyecto FONDECYT 1980200).

figuras antropomorfas. Visualmente este tipo permite al espectador acceder a un plano posterior, el de las piernas, evitando de esta forma que se enfrente ante ambigüedades en la representación. En esta tensión entre planos anterior -faldellíny posterior - piernas- se logra un atisbo de tridimensionalidad resuelta por la superposición de dos planos bidimensionales (Figura 5).

Pese a no encontrar representaciones con Faldellín Desdoblado en el río Salado este tipo pudo ser indirectamente relacionado con las expresiones pictóricas de estilo Cueva Blanca (Figuras 6, 7 y 8), Formativo Tardío Inicial (100-700 DC), a partir del trabajo de Sinclaire (1997). El eje de axialidad que estructura a los motivos antropomorfos portadores de esta prenda se hace extensivo a la figuración del faldellín el que se abre hacia los costados haciendo visible el soporte humano (Figura 9).

\section{Estados de lo visible. Una aproximación comparativa a semejanzas y diferencias en los esquemas representativos}

Estado uno: Transparencia y efectos de tridimensionalidad

El Faldellín Segmentado característico del estilo Confluencia se apropia de la morfología de su referente textil a la vez que asume la corporalidad de la figura (Montt, en prensa). Este estilo nos presenta figuras antropomorfas de gran anatomicidad por lo general erguidas y de perfil, algunas en un contexto escénico que claramente aluden a la caza por rodeo o chacu (Gallardo et al. 1999; Gallardo 1999).

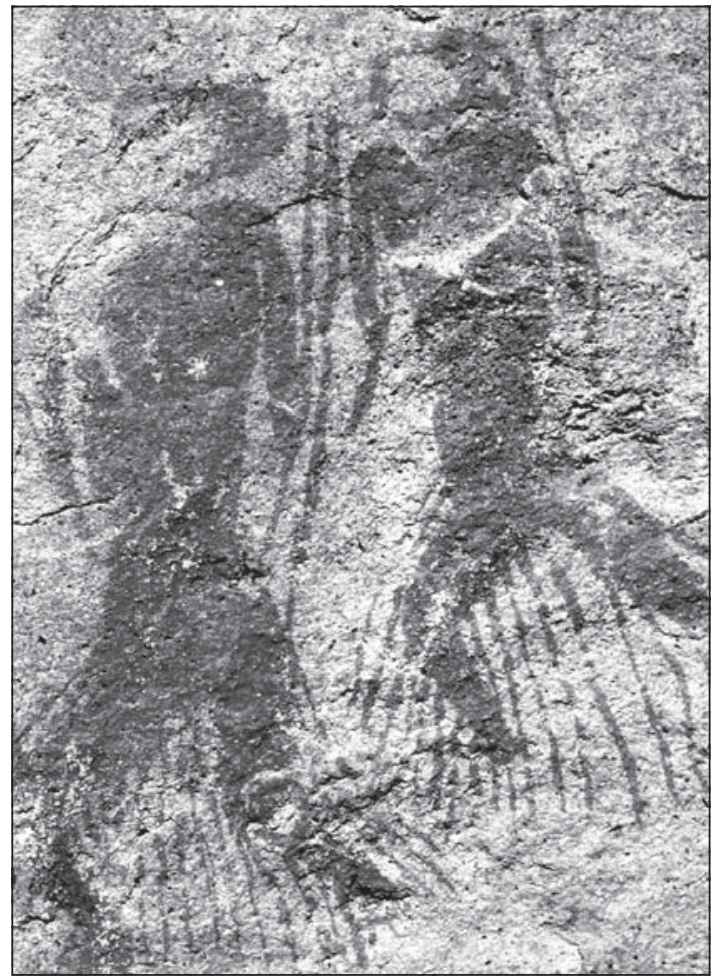

Figura 5. Transparencia, logro de tridimensionalidad relativa (archivo visual proyecto FONDECYT 1980200).

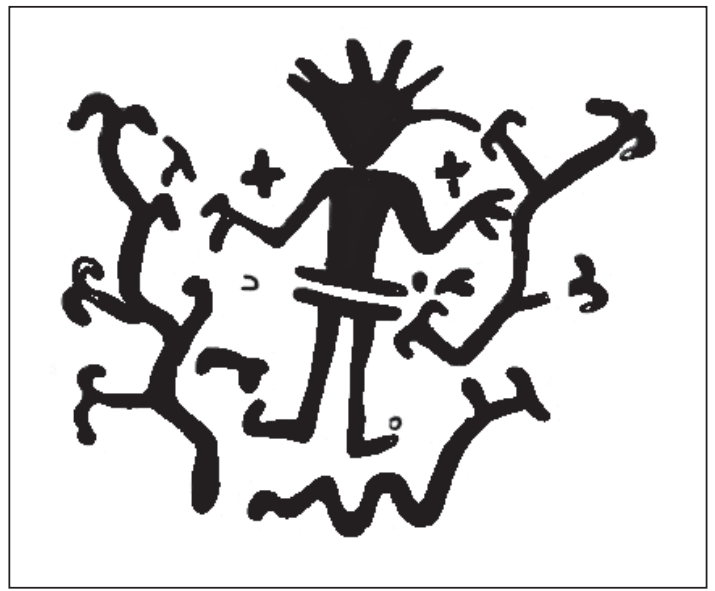

Figura 6. Figura antropomorfa, estilo Cueva Blanca (elemento en la cintura similar a aquel en figura antropomorfa de geoglifo Cerro Unitas) (archivo visual proyecto FONDECYT 1980200).

Existen otras representaciones en que es posible reconocer este Faldellín Segmentado, con ciertas variantes, pero siempre dentro del mismo esquema (Figura 10, en que la figura no presenta un desarrollo de los rasgos anatómicos ni de movilidad). Otras, son aquellas figuras publicadas por Núñez y 


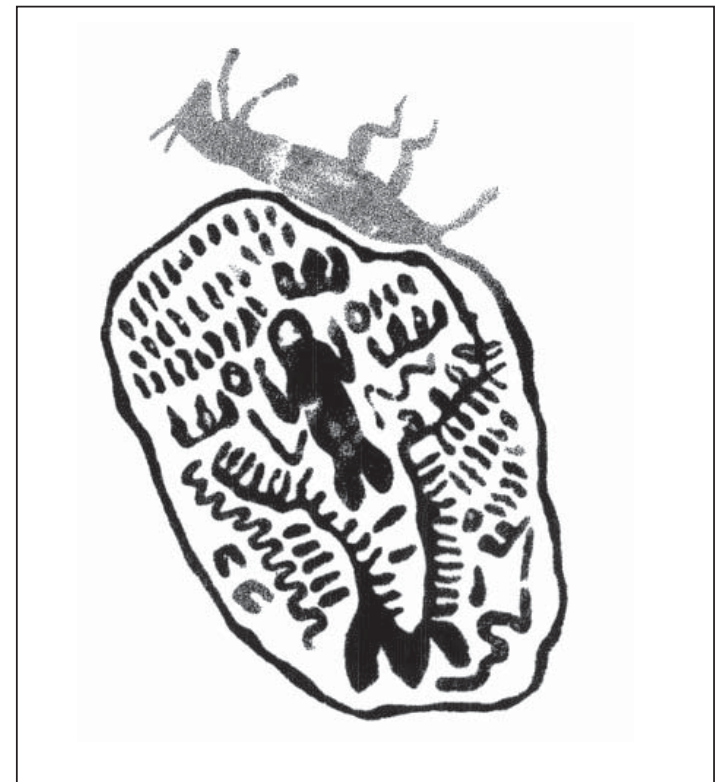

Figura 7. Figura antropomorfa, frontal y de brazos alzados, estilo Cueva Blanca (archivo visual proyecto FONDECYT 1980200).

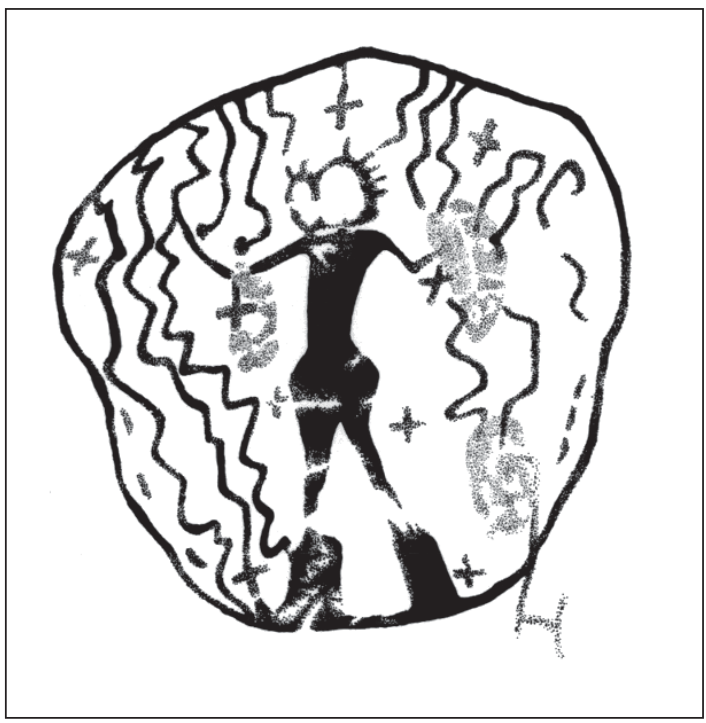

Figura 8. Figura antropomorfa, estilo Cueva Blanca (nótense rasgos anatómicos a la altura de la cintura) (archivo visual proyecto FONDECYT 1980200).

colaboradores (1997) para el Salar de Atacama. Al observar las representaciones Peine-1 (Figura 11) y San Lorenzo-1 (Figura 12) (Salar de Atacama) puede verse que se trata de un contexto formal y configurativo distinto a aquel Confluencia. El ejercicio pictórico en los sitios cercanos al Salar muestra obras con un claro énfasis en el dominio del color por sobre el de las formas del cuerpo.

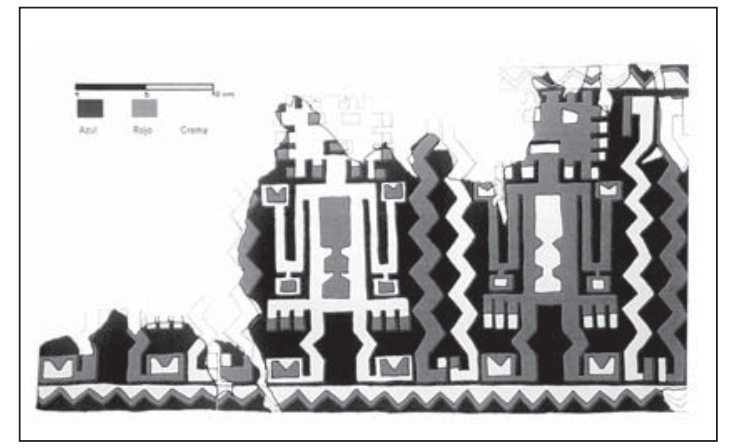

Figura 9. Faldellín Desdoblado en textil de Chorrillos (tomada de Sinclaire 1997).

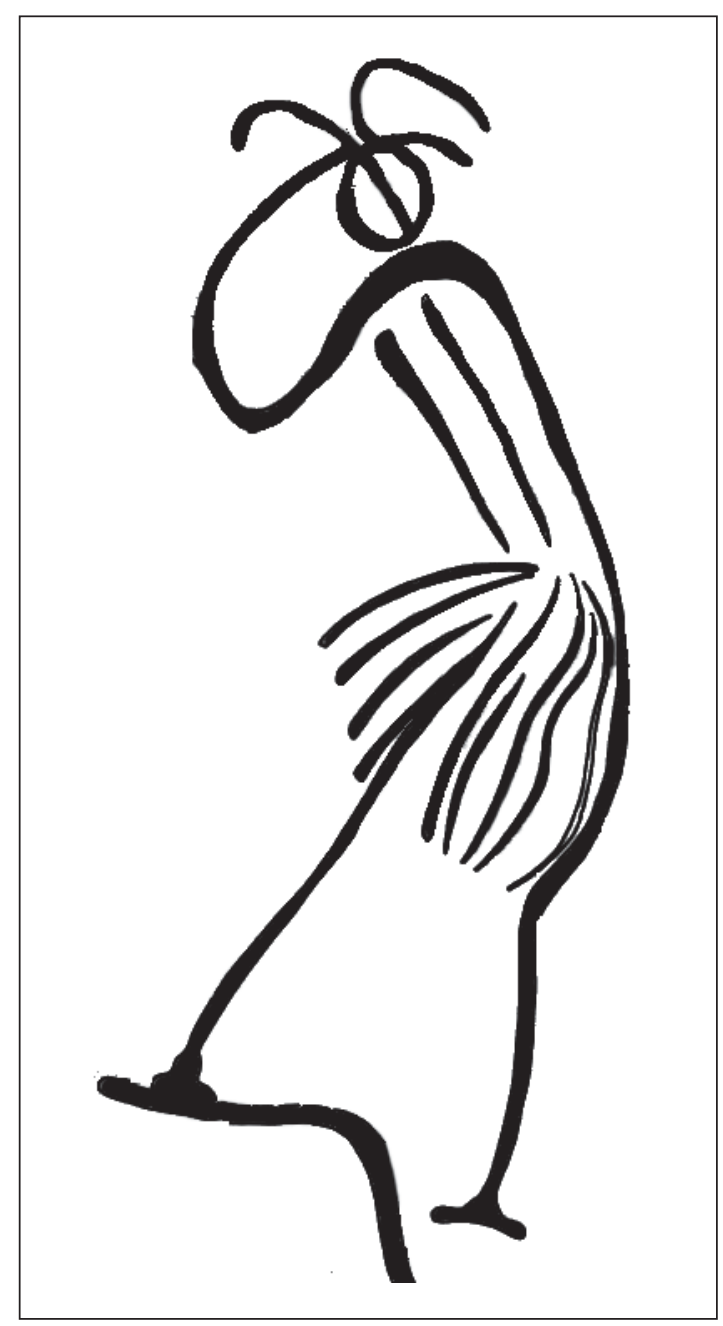

Figura 10. Faldellín Segmentado, una variante (archivo visual Proyecto FONDECYT 1980200).

Las representaciones del panel de la cueva de Peine fueron adscritas a diferentes estilos según Núñez (1995) y Núñez y colaboradores (1997). Es así 


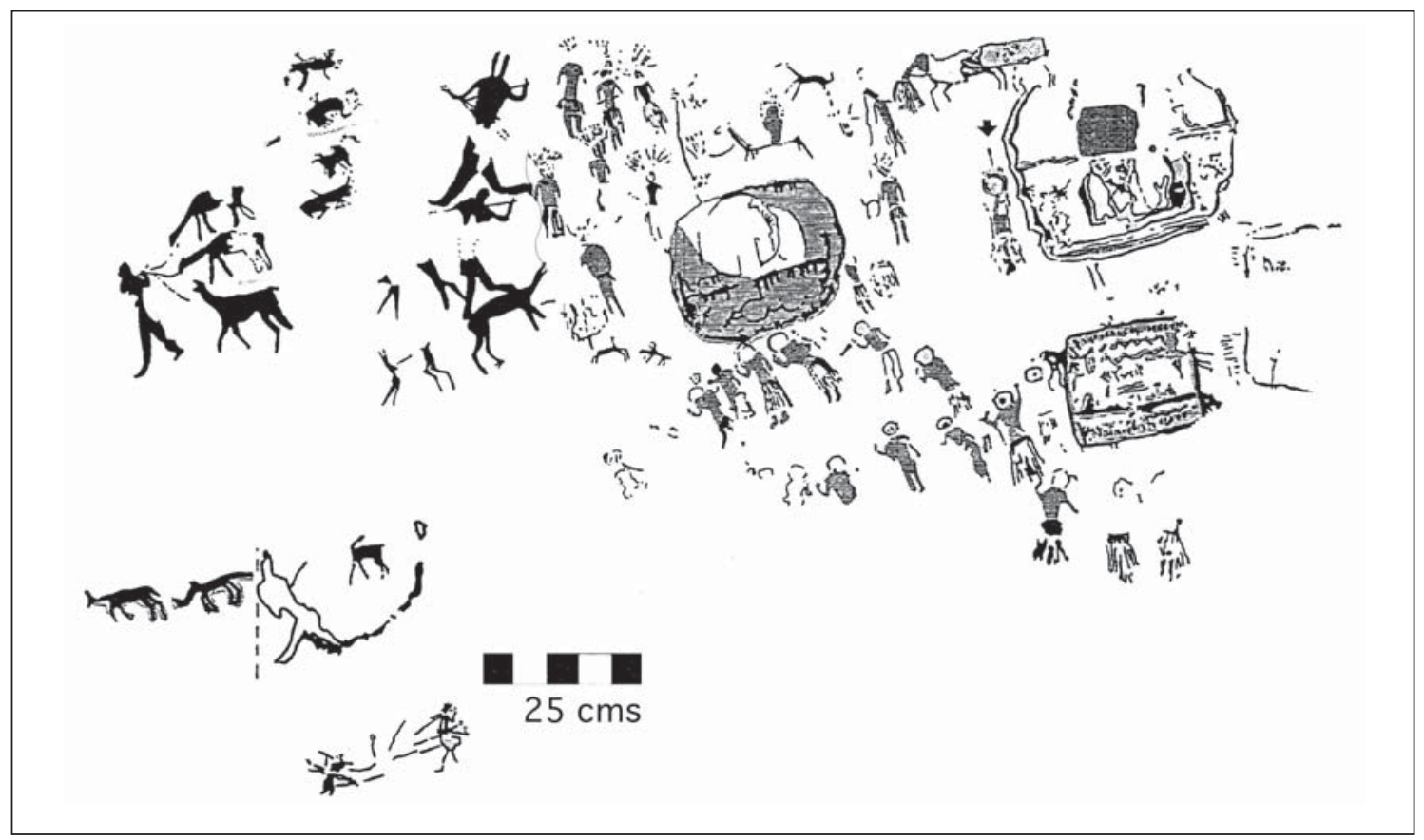

Figura 11. Panel y figuras antropomorfas con Faldellín Segmentado, Peine-1 (tomada de Núñez et al. 1997).

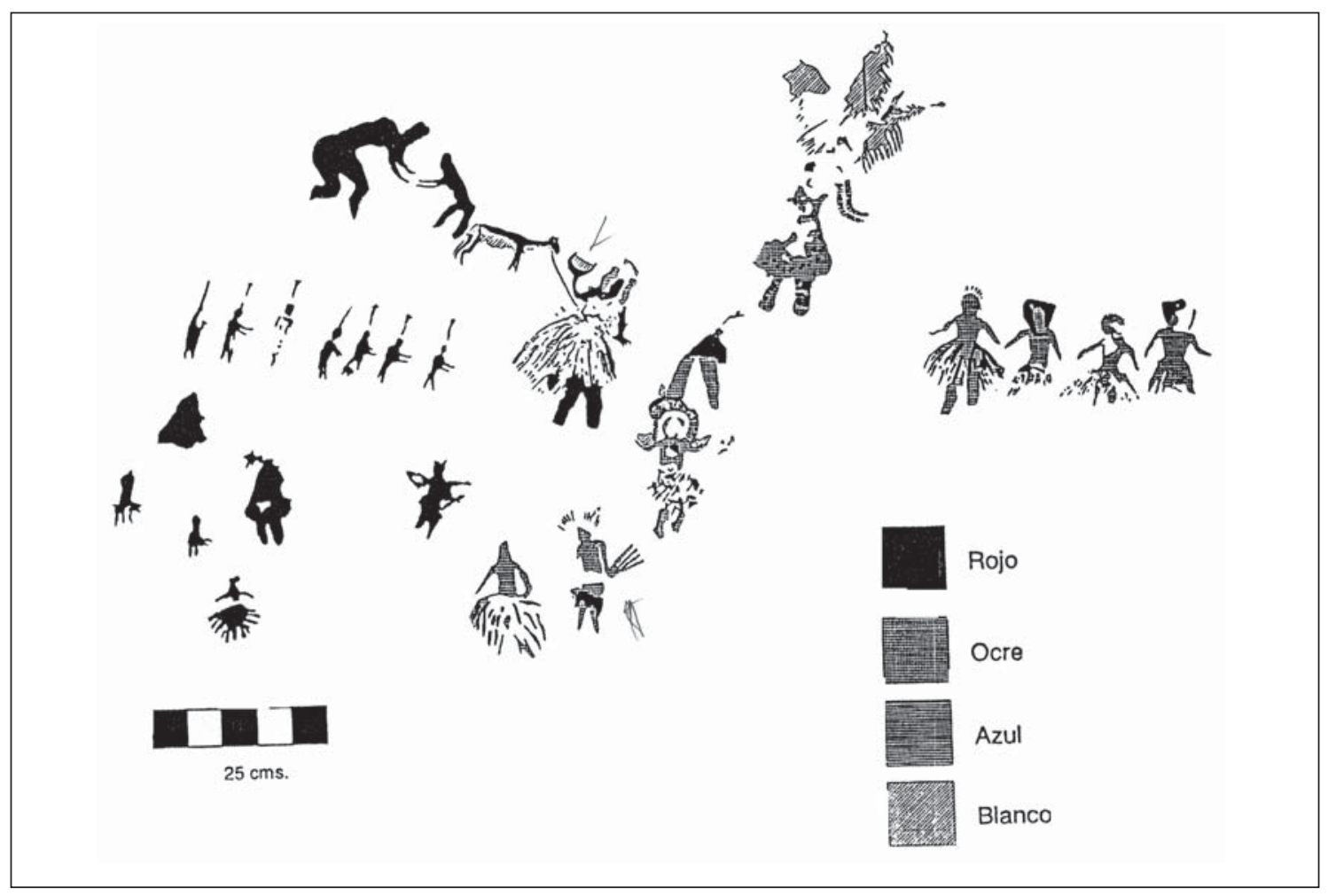

Figura 12. Panel y figuras antropomorfas con Faldellín Segmentado, sin logros de transparencia, San Lorenzo-1 (tomada de Núñez et al. 1997). 
como se define un estilo A que nombra la existencia de

"personajes naturalísticos y dinámicos que arrojan dardos a camélidos posiblemente abatidos. Un tercero los domina con tres sogas." (Núñez et al. 1997: 311; ver Figura 11 arriba izq.).

Los primeros conforman una escena que alude, según los autores, a eventos de protodomesticación o prácticas de pastoralismo; el segundo, en cambio, se vincularía con prácticas de caza (Núñez et al. 1997). Un estilo B es determinado a partir de motivos antropomorfos

"con cabezas discoidales blancas y abultadas (¿uso de turbantes?), complementados de coberturas púbicas o faldellines con piezas colgantes y adornos cefálicos sofisticados en el sector superior" (Figura 11, lado der.).

Pese a que el interior de la cueva no cuenta con depósitos arqueológicos, se propone una data arcaica tardía a formativa para estas evidencias.

Cabe destacar que la posición frontal de algunos de estos antropomorfos es coherente con una construcción escénica que, en esta parte, no demanda un vínculo hombre-animal (Figura 13). Por otra parte, es posible notar que las figuras antropomorfas en actitud de caza detentan un gesto técnico similar a aquel observable en el estilo Confluencia (1400 AC-100 DC). Estas a su vez se observan en aparente asociación a una tercera que conduce a sus animales a través de una soga, actitud que también es visible en una figura con Faldellín Segmentado del conjunto San Lorenzo-1. Las expresiones rupestres de este último sitio muestran motivos antropomorfos con "coberturas púbicas o faldellines de piezas colgantes y cabezas abultadas (¿uso de turbantes?)" advirtiéndose también "el uso de tocados cefálicos sofisticados, personajes con dardos y camélidos atados al cuello.” (Núñez et al. 1997: 309; ver Figura 12).

No obstante ser las figuras frontales de Peine y San Lorenzo conservadoras en cuanto a la exposición de dos planos de representación, no son construidas apelando a un perfil. Por otra parte, aquellas figuras de San Lorenzo exhiben un abultado faldellín cuyo espacio entre pabilos está rellenado con pintura de color más claro. Esta figura cuenta con un gesto en su mano de notable parecido a otra hallada en la quebrada de Caspana (Figura 14). Todas estas soluciones, además de constituir variantes en relación al panorama temprano del río

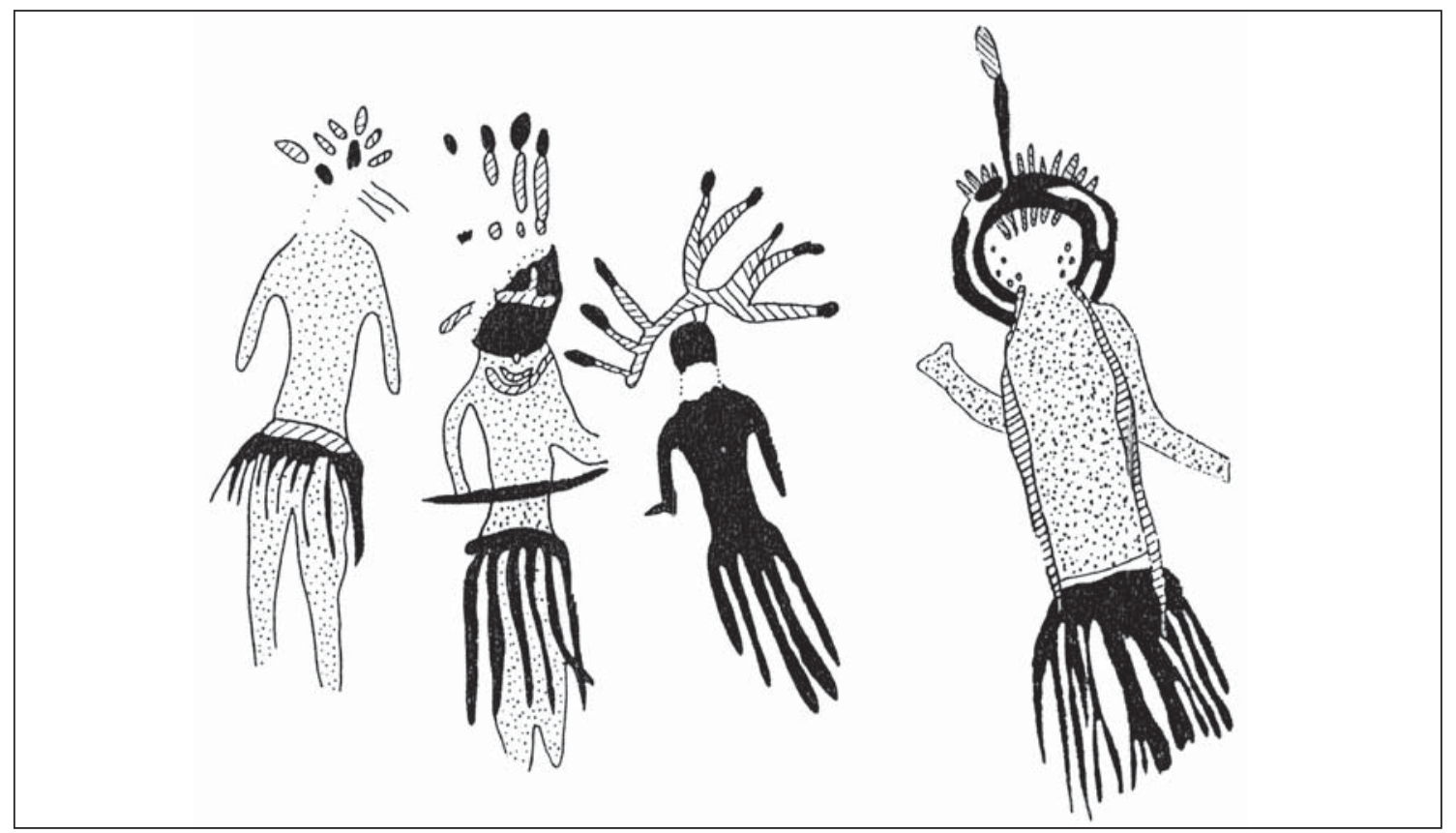

Figura 13. Figuras antropomorfas frontales, transparencia relativa, Peine-1 (detalle) (tomada de Núñez et al. 1997). 


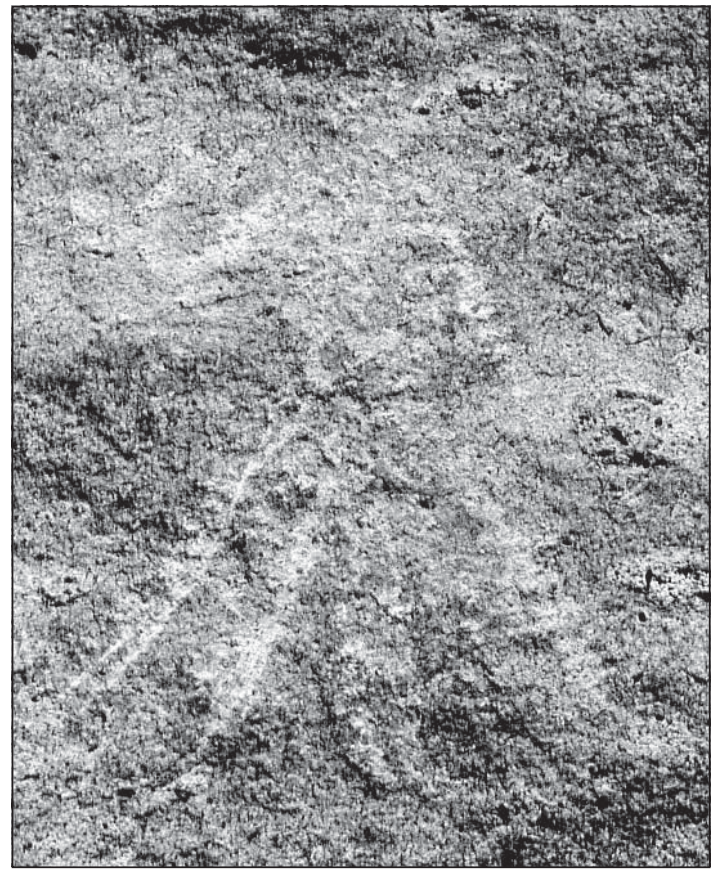

Figura 14. Grabado sobre bloque rocoso, Quebrada de Caspana, aguas arriba del pueblo, margen sur.

Salado, cuentan con efectos que les restan convicción para efectos de la tridimensionalidad.

Las representaciones de Peine están pintadas en superposición bajo motivos que recuerdan a aquellos Cueva Blanca (Figura 11; Figuras 6, 7 y 8, respectivamente) y, según Núñez y colaboradores (1997: 311), corresponderían a manifestaciones de "etapas postformativas, al parecer, provenientes de ocupaciones agrarias locales". Al considerar que las expresiones rupestres Cueva Blanca corresponden al Formativo Tardío Inicial, Fase Turi-2A (100700 DC) en la cuenca alta del río Salado (Sinclaire, en prensa), son dos los planteamientos preliminares que pueden ser sugeridos: primero, que las evidencias correspondientes al estilo B de Núñez y colaboradores, bajo estos motivos de parecido a Cueva Blanca, pueden ser consideradas como pre 100 DC, es decir, fines del Formativo Temprano ${ }^{8}$, esto también a juzgar por la presencia en este estilo B de figuras con Faldellín Segmentado y Tocado Semirradial, tipo de atuendo preponderantemente Formativo Temprano en la zona antes referida (Montt,

8 Correspondiente a la Fase Toconao 300 AC-100 DC, para el Salar y Fase río Salado 500 AC-100 DC, para la cuenca alta del Salado. en prensa), lo cual se ve reforzado por una composición que privilegia una postura de frente, rasgo que se observa en momentos más tardíos del Formativo en el Salado.

Estado dos: Soluciones de desplazamiento o desdoblamiento y tensión en lo bidimensional

Desplazamiento. En el estilo A definido para la cueva Peine-1 es posible observar dos figuras en lo que parece ser actitud de caza. Estas representaciones son de gran relevancia ya que nos sitúan ante dos contextos figurativos de interacción formativa hombre-camélido, con el Faldellín Segmentado como atuendo: en primer término, en la Subregión de río Salado, tenemos aquellas escenas de estilo Confluencia representando figuras antropomorfas en actitud de caza. Por otra parte, en el Salar, las figuras con este tipo de representación de vestimenta o están participando de escenas cuyo tema es aún indefinible (estilo B) o están "conduciendo" al o los camélidos a través de una "soga", 9 tema que se presenta en el Salado únicamente en una pintura del sitio La Cueva (Cupo) (Figura 15). Esta muestra una figura antropomorfa vistiendo Faldellín Segmentado en una disposición diferente a las figuras presentadas como Confluencia: los pabilos caen entre las piernas, las que a su vez fueron abiertas para que la prenda luciera; de la mano derecha sale un trazo lineal que la vincula al cuello de un camélido. Como señalé con anterioridad, este tema no se repite en otras partes de la Subregión lo que hace a esta escena bastante singular. Las figuras 16, 17

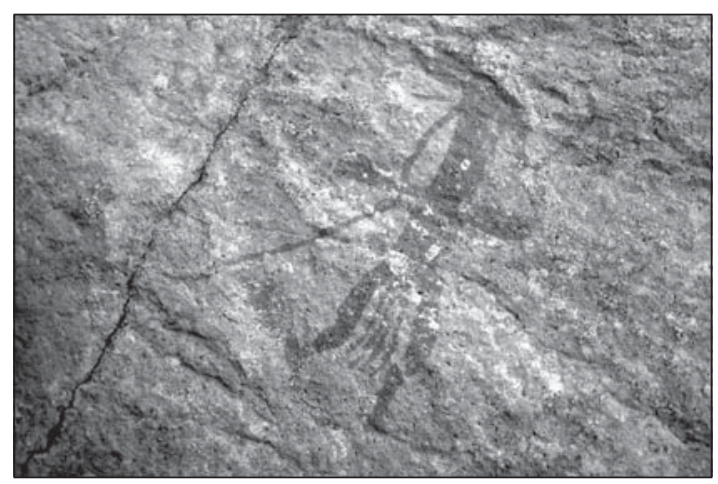

Figura 15. Faldellín Segmentado entre las piernas, Quebrada de Cupo (archivo visual Proyecto FONDECYT 1980200).

9 Trazo lineal que une el cuello del camélido con la mano de la figura antropomorfa. 


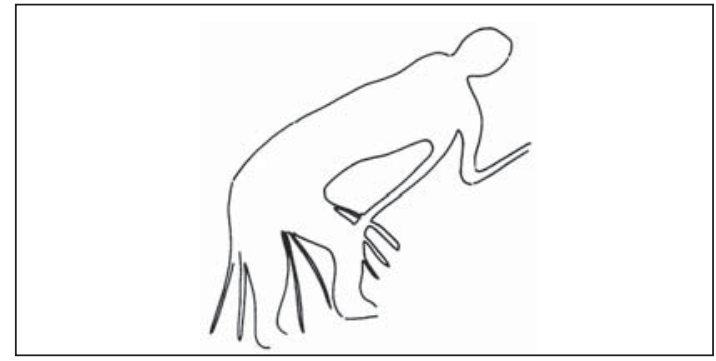

Figura 16. Figura antropomorfa con Faldellín Segmentado, desplazado (nótese la disposición de los brazos, intentando permanecer coherente con una construcción de perfil, tanto de torso como de piernas) (archivo visual Proyecto FONDECYT 1980200).

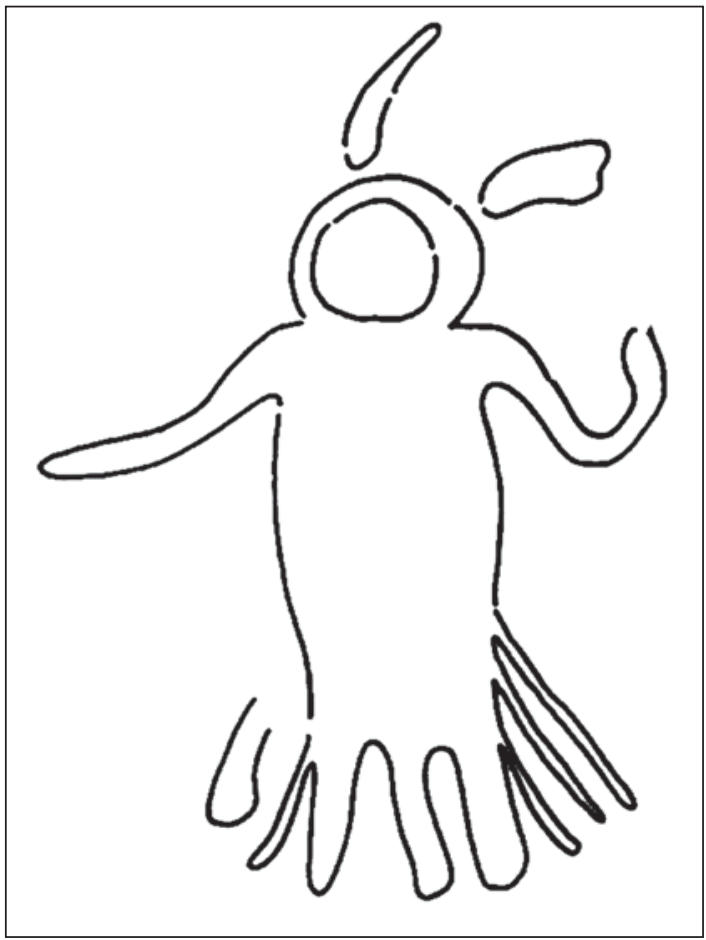

Figura 17. Figura antropomorfa con Faldellín Segmentado, desplazado (archivo visual Proyecto FONDECYT 1980200).

y 18 , también de la cuenca alta del río Salado confirman la existencia de Faldellines Segmentados sin intentos de transparencia ni tridimensionalidad, en representaciones antropomorfas bidimensionales, frontales y de perfil parcial (troncos frontales-piernas de perfil). De estas imágenes, es la de La Cueva la única que cuenta con referencias cronológicas, al haberse adscrito el depósito adyacente a un Período Intermedio Tardío inicial.

Desdoblamiento. Otro foco de discusión puede ser abierto en torno a las imágenes de figuras antro-

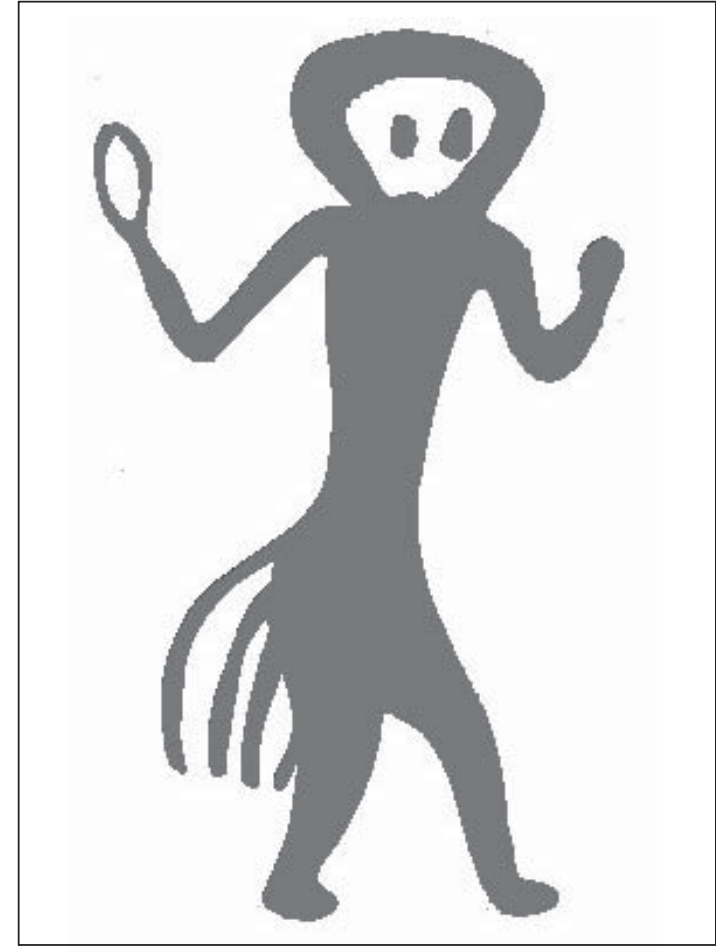

Figura 18. Figura antropomorfa con Faldellín Segmentado, desplazado (archivo visual Proyecto FONDECYT 1980200).

pomorfas vistiendo Faldellín Tipo Desdoblado. Como fue señalado, este tipo de vestimenta no se encuentra en las representaciones de la Subregión de río Salado; no obstante, su estudio se hace pertinente al estar representada en los textiles formativos tardíos de Chorrillos, uno de los potenciales referentes para el estilo Cueva Blanca (Sinclaire 1997).

El Faldellín Tipo Desdoblado va generalmente en asociación al Tocado Tipo Radial (Montt, en prensa), elemento que sí es posible apreciar en las figuras del Salado, haciéndose frecuente en el estilo Cueva Blanca (Montt, en prensa). Ambos elementos de atuendo son exhibidos por imágenes antropomorfas construidas a base de un esquema de axialidad en el cual la figura está gobernada por la ortogonalidad y la simetría, siguiendo un patrón significante de desdoblamiento especular (sensu Mege 1998 Ms: 57). El proceso de construcción del significante, suprime lo anatómico e instaura en el plano de la representación una concepción fijista (Mege 1998 Ms: 58). Las figuras y los tipos de atuendo que analizaremos a continuación siguen de cerca estas convenciones, las que son seguramente depositarias de un esquema constructivo que cautelosamente podría- 
mos denominar panandino, posiblemente repopularizado al momento de los contactos entre el Norte Grande y la Subárea Circumtiti-caca. Las imágenes humanas construidas en este modelo o esquema constructivo, basado en la axialidad, presentan en sus aspectos configurativos múltiples combinaciones y gran variabilidad; sin embargo, puede observarse como recurso visual estable la representación antropomorfa en frontalidad con sus brazos alzados.

Esto se hace manifiesto al ver en conjunto la figurita de oro de Guatacondo (Figura 19), la figura del Panel 7 del sitio 2-Loa 231 (Figura 20), la de Vilama Sur (Figura 21), aquellos grabados antropomorfos con atuendo de Ariquilda y Tamentica (Figuras 22 y 23, respectivamente), el textil de Chorrillos (Figura 9), todas ellas con un Faldellín Desdoblado, cuyo despegue es asignable al Período Formativo Tardío. En estas imágenes, al igual que en las logradas a través de soluciones de desplazamiento, existe un trabajo exclusivamente desarrollado en las dos dimensiones (ancho-alto), lo que obliga en este caso al artista o artesano al corte y desdoblamiento del sujeto y el faldellín. ${ }^{10}$

La dispersión de representaciones antropomorfas construidas bajo un esquema de axialidad abarca todo el Norte Grande, desde los Valles Occidentales hasta el salar de Atacama. Este estereotipo ha sido tratado con diferentes nombres: "Caravanero", "Hombre-cóndor", "Tunupa", "Señor de La Isla", "Icono de Chorrillos", "Señor de los Báculos" y "Ser Mítico" entre otros que seguramente podrían ser registrados o definidos. Diversas investigaciones han intentado una explicación para los orígenes de esta imagen, encontrando antecedentes en la litoescultura Pukara o Chiripa (Sinclaire 1997), o bien Tiwanaku (Berenguer 1981). Asimismo, los motivos encontrados por Uhle en piezas de Pisagua, según él, contemporáneos a las ruinas de Chavín, fueron considerados por Berenguer como motivos derivados de Paracas (Berenguer 1981; ver también Chacama y Espinoza 1997).

10 Este faldellín desdoblado fue llamado por Chacama y Espinoza (1997: 784) "faldellín alado", siendo considerado por estos autores como la "síntesis de las alas de un ave", perspectiva que este estudio no comparte por tratarse, entre otros argumentos que podrían ser esgrimidos, de un elemento fijado a la figura antropomorfa a la altura de la cintura y no de los hombros.
Efectivamente, Uhle reconoce la época de ciertos hallazgos en Punta Pichalo como sincrónicos con Chavín o protonazcas a partir de:

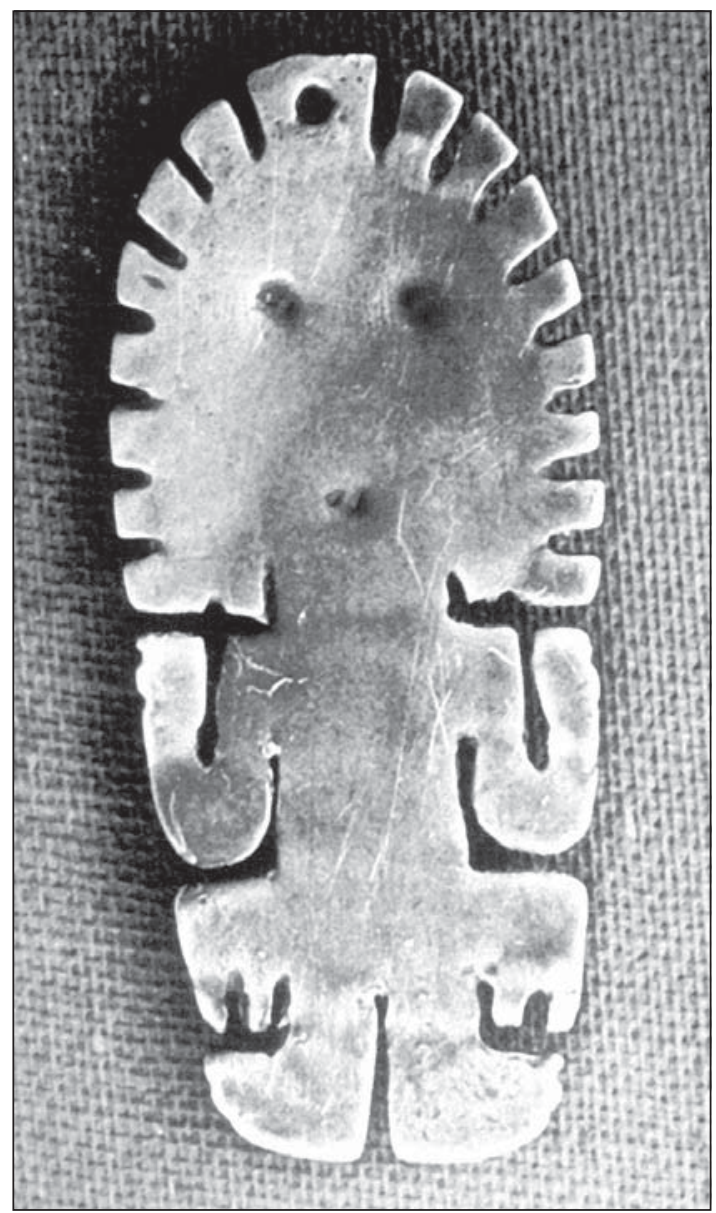

Figura 19. Faldellín Desdoblado, figura de oro de Guatacondo (tomada de Mostny y Niemeyer 1983).

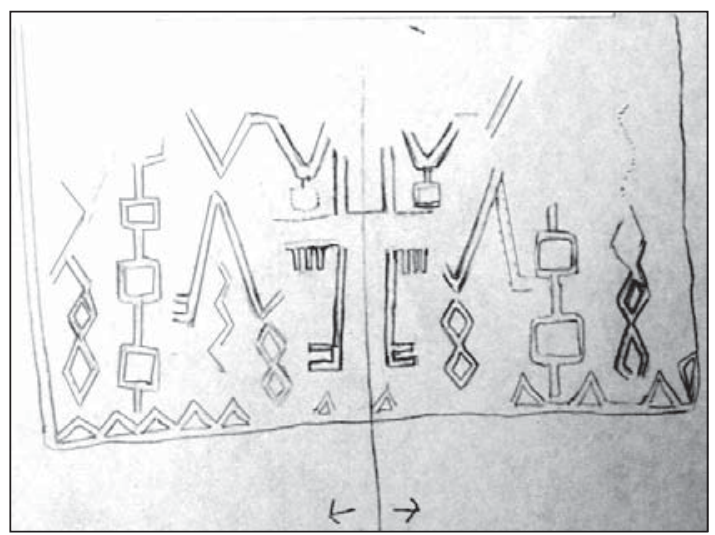

Figura 20. Arte rupestre, sitio 2-Loa 231, Alto Loa (dibujo de C. Sinclaire). 


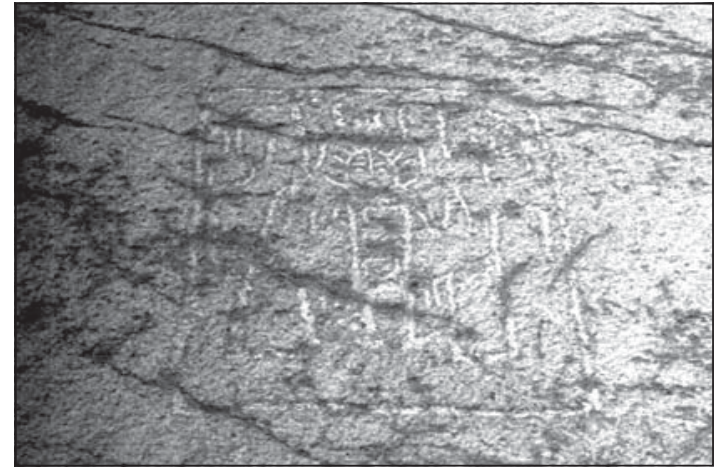

Figura 21. Arte rupestre, Vilama Sur (archivo visual proyecto FONDECYT 1000148).

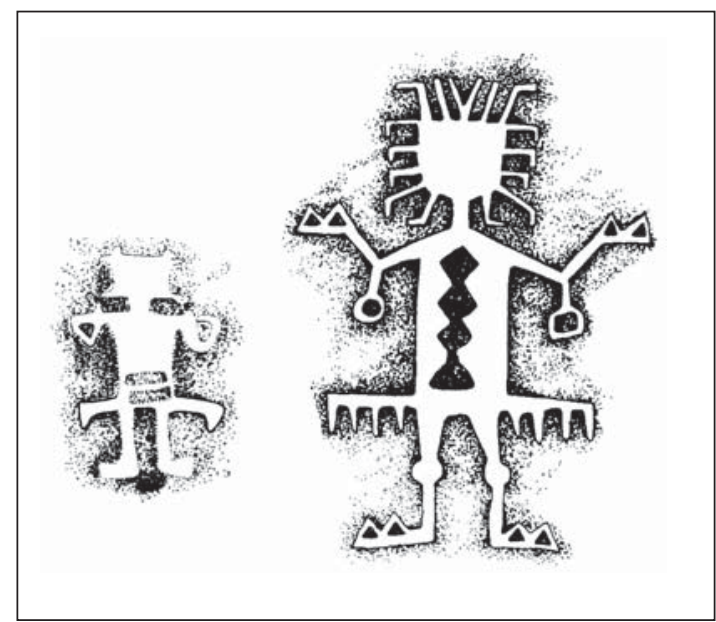

Figura 22. Figuras antropomorfas, Ariquilda, Quebrada de Aroma (tomada de Chacama y Briones 1996).

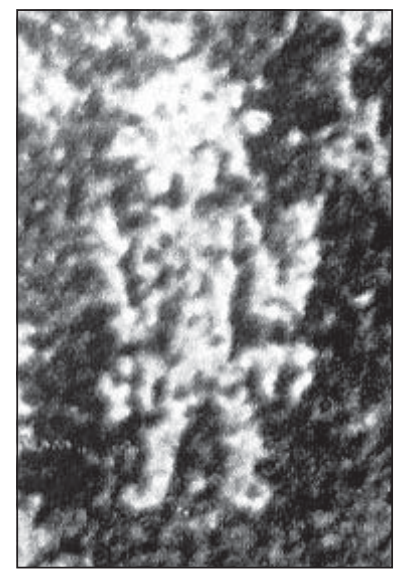

Figura 23. Figura antropomorfa con Faldellín Desdoblado, Tamentica, Quebrada de Guatacondo (tomada de Mostny y Niemeyer 1983). "las figuras tejidas en algunas bolsas, que se han encontrado en las mismas sepulturas [...] Son figuras de hombres y de serpientes y ciertos dibujos meándricos grandes. Las primeras se presentan de frente, adornada la cabeza con un plumaje, y en la cintura llevan una faja terminada por los dos lados por cuellos de serpientes, como en los estilos de protonazca, protochimu y Chavín" (Uhle 1922: 71).

Sin duda, la reseña anterior coincide con las imágenes tejidas en la bolsa que se presentamos (Figura 24) la que, siendo adscrita al cementerio D de Pisagua (llamado "Protonazca" por Uhle), puede situarse entre el 890 AC y el 290 DC (sensu Agüero 1994).

La única constante formal (forma actual) en todas las imágenes referidas, además de la frontalidad de la figura, está dada por los brazos alzados y la existencia de tocado. En lo que respecta a los elementos de atuendo que portan las figuras, la forma y disposición de sus partes anatómicas (sobre todo piernas), los motivos que se le asocian, los soportes que le sustentan, o bien su materialidad y su distribución espacial, reflejan una versatilidad y combinatorias que parecieran ser infinitas, sobrepasando los alcances de este trabajo. En este sentido, se precisa de una incursión sistemática en los diferentes aspectos que

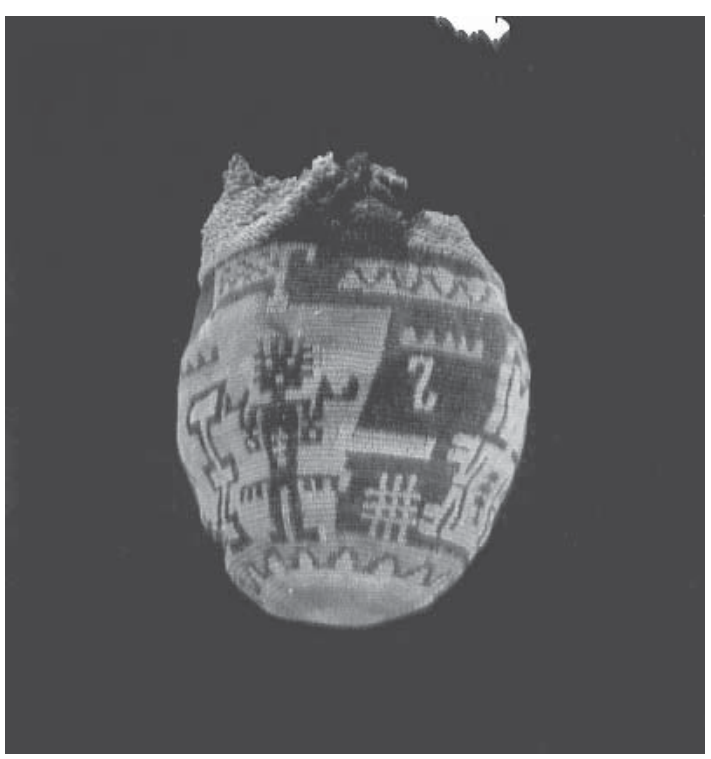

Figura 24. Figura antropomorfa frontal de brazos alzados, con Faldellín Desdoblado, en bolsa del cementerio D "Protonazca" de Pisagua (archivo visual proyecto FONDECYT 1960169). 
presenta este icono antropomorfo, los que, sumados a un estudio del contexto arqueológico asociado, permitirían quizás discriminar si la variabilidad observable responde a motivaciones de carácter espacial-distribucional, temporal-cronológico o estilístico, explorando en el modo como el imaginario local asume y reformula este modelo representativo, en desmedro de simples apropiaciones.

La ruptura en términos formales, configurativos y temáticos con respecto a las expresiones revisadas en los acápites previos, es notable. La forma efectiva de estas imágenes no apela a una socialidad antropomorfo-zoomorfo o antropomorfo-antropomorfo. Existe un emplazamiento claro al espectador, un frente a frente por parte de una figura que se vuelve dominante en términos de composición.

\section{Conclusiones}

A través de estas páginas, a partir del análisis de figuras antropomorfas y sus faldellines, se ha intentado escribir una historia de las soluciones visuales en el ámbito de la representación plana. Si bien la representación de faldellines durante el Formativo -como atuendo privilegiado en la representación pictórica de los antropomorfos- carece de un significado traducible, puede leerse a través del devenir de su construcción visual un proceso que cifra una forma particular de ver y representar la realidad, social y material. Es así como esta prenda no comporta el reflejo pasivo de un objeto, sino de una praxis social en relativa, pero constante, transformación. Es en este campo de experimentación visual, y sus correlativos recursos formales, que se despliegan los atributos que se han ido rastreando. El proceso que da lugar a esta situación es lo que en lenguaje de Gombrich se conoce como "esquema y corrección" (Gombrich 1969). Este, a grandes rasgos, marca un ritmo en que, a partir de logros ya establecidos, se realizan combinaciones y reemplazos dando lugar a nuevas obras, en las que es reconocible el esquema primario que les dio forma.

Primeramente, el ejercicio desarrollado a través de los logros o, más bien, atisbos de tridimensionalidad basada en la transparencia del faldellín, nos emplazan ante sujetos sociales capaces de mostrar una imagen con aparente realismo, pese a los desajustes provocados en el intento de presentar cada parte del cuerpo girada hacia su pla- no más completo. La dispersión de este tipo de esquema en el paisaje nos sitúa frente a un arte que se repliega en ciertos enclaves, todos ellos definidos por áreas de reparo (aleros y cuevas), siendo caracterizado por figuras de un tamaño que demanda cierta proximidad por parte del espectador. La socialidad entre hombres y animales se desenvuelve en una forma igualitaria, sin ser establecidas jerarquías al interior de las configuraciones. Esto sucede en una época de profundos y paulatinos cambios en términos de producción, tanto en lo que se refiere al modo como a las relaciones sociales implicadas en este proceso.

"Esto nos obliga a volver la mirada hacia la vida social y el crítico proceso vivido por las comunidades durante el Formativo Temprano Inicial, época que marca la transición entre un modo de producción donde los frutos del trabajo social eran probablemente redistribuidos (Arcaico Tardío) y otro en que la riqueza producida en el intercambio podía ser apropiada individualmente (Formativo Tardio). A su modo, el arte rupestre testimonia aquí las profundas contradicciones habidas entre gentes cuyo modo de vida cazador estaba legitimado por una historia y sólida tradición, y otro que, sostenido en el pastoreo de llamas promovía nuevos roles sociales y una economía excedentaria nunca antes vista" (Gallardo 2000: 8).

Este esquema profundamente referencial, marcado por una fidelidad hacia las apariencias de la realidad material y por una imagen de socialidad simétrica en la interacción hombre-camélido, podría estar indicando un arte que objetiva en el imaginario la fijación de un estado marginal o residual, que se resiste a los nuevos cambios.

A partir del Formativo Tardío se articulan ciertos cambios en torno a las figuras antropomorfas y a la imagen del faldellín en particular. A escala local (cuenca alta del río Salado) estaría operando una desestabilización parcial de los cánones representativos tempranos: vemos figuras que, representando el faldellín con indicación de sus pabilos, no apelan al efecto de transparencia, desplazando la prenda y situando en un mismo plano piernas y faldellín. Estas imágenes estarían planteando cierta continuidad en lo a que motivos se refiere -faldellines- cambiando el modo en que estos se vierten en la representación. Paralelamente, se identifican figuras humanas frontales y de brazos alzados, adscritas al estilo Cueva Blan- 
ca. Por otra parte, a una escala macrorregional (Norte Grande de Chile, al menos) se difunde la figura frontal de brazos alzados, también evidenciando en algunos casos los pabilos colgantes del faldellín, el que se "desdobla" a partir del eje axial que estructura a la misma figura antropomorfa. En este punto estamos ante una imagen lejana de la visión de la realidad y más cercana a la construcción conceptual de esta, determinando una construcción formal basada en convenciones que poco intentan el logro de un parecido con sus referentes. Al decir convención se apunta a un acuerdo entre quien "hace ver" y quien "ve", el cual comporta un consenso que, desde el autor, se impone.

Teniendo en consideración la paulatina baja en la frecuencia de faldellines a partir del Formativo Tardío, se vuelve relevante el hecho de que estos se fijen en un imaginario que los actualiza en la cultura visual, a partir de piezas y paneles que, aunque pocas, cuentan con una amplia distribución espacial. Esto se traduce en una persistencia de referentes tempranos, seguramente secundarios en cuanto a su uso efectivo como vestimenta (en relación a otras prendas), los que son adoptados en la construcción de una imagen de alta circulación, como la figura frontal.

La serie de imágenes que se ha presentado responde a una producción visual que, junto con in- cluir la figura humana dentro de su repertorio la viste con el faldellín, contando para ello con un variable, pero limitado conjunto de posibles opciones. Lo que aquí se ha ensayado, en palabras de Ginzburg (1999: 70), es la reconstrucción de los vínculos y de las relaciones de dependencia o de contraposición que unen a las distintas figuras. El contexto social en el cual se desarrollan estos distintos esquemas relacionales y sus constantes modificaciones sin duda está marcado, a partir de los momentos finales del Formativo, por una reorientación de las demandas visuales. En estas, los límites de la semejanza con las apariencias de la realidad se ensanchan y la mirada del observador se somete a un vínculo directo e instrumental con la imagen, por sobre una socialidad antes resuelta al interior de la obra rupestre.

Agradecimientos Primeramente, mi enorme gratitud a Francisco Gallardo junto a quien inicié este inacabable asomo a la cultura visual del Norte Grande: gracias por tu noble generosidad y constante apoyo. Agradezco a Silvia Quevedo por invitarme a registrar el material misceláneo de la Colección Uhle (Aborígenes de Arica y Protonazca), compartiendo conmigo el registro de la bolsa de Punta Pichalo que aquí se presenta. Por último, gracias a Gonzalo Pimentel y los caminos que me mostraron nuevas imágenes de Caspana.

\section{REFERENCIAS CITADAS}

AGÜERO, C., 1994. El cementerio "Protonazca" (D) de Pisagua. Análisis de la textilería. Hombre y Desierto 9: 7-20.

BARTHEL, T., C. MUNIZAGA y A. MEDINA, 1959. Nota preliminar sobre las pinturas parietales de los refugios de Sirantur. Boletín Americanista 3: 171-174.

BERENGUER, J., 1981. En torno a los motivos biomorfos de la Puerta del Sol en el norte de Chile. Boletín del Museo Nacional de Historia Natural 38: 167-182.

-1995. El arte rupestre de Taira dentro de los problemas de la arqueología atacameña. Chungara 27 (1): 7-43.

-1996. Identificación de camélidos en el arte rupestre de Taira: ¿Animales silvestres o domésticos? Chungara 28 (1 y 2 ): 85-114.

1999. El evanescente lenguaje del arte rupestre en los Andes atacameños. En Arte rupestre en los Andes de $\mathrm{Ca}$ - pricornio, J. Berenguer y F. Gallardo (Eds.), pp. 9-56. Museo Chileno de Arte Precolombino, Santiago.

BERENGUER, J. y J. L. MARTINEZ, 1986. El río Loa, el arte rupestre de Taira y el mito de Yakana. Boletín del Museo Chileno de Arte Precolombino 1: 79-99.

BERENGUER, J., V. CASTRO, C. ALDUNATE, C. SINCLAIRE y L. CORNEJO, 1985. Secuencia del arte rupestre en el Alto Loa: Una hipótesis de trabajo. En Estudios en Arte Rupestre, C. Aldunate, J. Berenguer y V. Castro (Eds.), pp. 243-264. Museo Chileno de Arte Precolombino, Santiago.

CASTIÑEIRAS, M. A., 1998. Introducción al método iconográfico. Editorial Ariel, Barcelona.

CHACAMA, J. y L. BRIONES, 1996. Arte rupestre en el desierto tarapaqueño, Norte de Chile. Boletín SIARB 10: $41-51$ 
CHACAMA, J. y G. ESPINOZA, 1997. La ruta de Tarapacá. Análisis de un mito y una imagen rupestre en el norte de Chile. Contribución Arqueológica 5 (I): 769-791.

DRANSART, P., 1997. Rockshelters and ritual activities in the Atacama Desert of Northern Chile. En The human use of caves. C. Bonsall y C. Tolan-Smith (Eds.), pp. 207-215. BAR International Series 667, Oxford.

GALLARDO, F., 1999. Arte, arqueología social y marxismo: Comentarios y perspectivas (Parte I). Boletín de la Sociedad Chilena de Arqueología 26: 37-41.

-En prensa. El arte rupestre como ideología: Un ensayo acerca de pinturas y grabados en la localidad del río Salado (desierto de Atacama, Norte de Chile). En Actas del XV Congreso Nacional de Arqueología Chilena, Arica, 2000.

GALLARDO, F., C. SINCLAIRE y C. SILVA, 1999. Arte rupestre, emplazamiento y paisaje en la cordillera del desierto de Atacama. En Arte rupestre en los Andes de Capricornio. J. Berenguer y F. Gallardo (Eds.), pp. 57-96. Museo Chileno de Arte Precolombino, Santiago.

GINZBURG, C., 1999. Mitos, emblemas, indicios. Morfología e historia. Editorial Gedisa, Barcelona.

GOMBRICH, E. H., 1969. Art and illusion. Bollingen Series XXXV 5, Princeton University Press, Princeton.

KUltermanN, U., 1996. Historia de la Historia del Arte. El camino de una ciencia. Ediciones Akal, Madrid.

LATCHAM, R., 1938. Arqueología de la región atacameña. Prensas de la Universidad de Chile, Santiago.

MEGE, P., 1998 Ms. Herramientas semiológicas para el análisis e interpretación de la pintura rupestre.

MASON, P., 1998. Infelicities. Representations of the exotic. The Johns Hopkins University Press, Londres.

MONTT, I., en prensa. Elementos de atuendo e imagen rupestre en la Subregión de río Salado, Norte Grande de Chile. En Actas del XV Congreso Nacional de Arqueología Chilena, Arica, 2000.

MOSTNY, G. y G. KUNSEMÜLLER, 1960. Informe preliminar de la expedición al río Loa Superior. Primera Par- te. Noticiario Mensual del Museo Nacional de Historia Natural 44: 5-6.

MOSTNY, G. y H. NIEMEYER, 1983. Arte rupestre chileno. Serie El Patrimonio Cultural Chileno. Publicación del Departamento de Extensión Cultural del Ministerio de Educación, Santiago.

NUÑEZ, L., 1995. Arte rupestre y rutas entre el río Loa Medio y la Cuenca de Atacama. Resumen del Simposio Internacional de Arte Rupestre andino. Universidad de Tarapacá, Departamento de Antropología y Museo, Arica.

NUÑEZ, L., I. CARTAJENA, J. P. LOO, S. RAMOS, T. CRUZ, T. CRUZ y H. RAMIREZ, 1997. Registro e investigación del arte rupestre en la cuenca de Atacama (informe preliminar). Estudios Atacameños 14: 307-325.

PANOFSKY, E., 1972. Estudios sobre iconología. Alianza Universidad, Madrid.

PLAGEMANN, A., 1906. Über die chilenischen "Pintados". XIV Amerikanisten Kongress, Stuttgart.

RAPHAEL, M., 1968. The demands of art. Bollingen Series LXXVII, Princeton University Press, Princeton.

RYDEN, S., 1944. Contributions to the archaeology of the rio Loa Region. Elanders Boktrickery Aktiebolag, Göteborg.

SINCLAIRE, C., 1997. Pinturas rupestres y textiles formativos en la región atacameña: Paralelos iconográficos. Estudios Atacameños 14: 327-338.

-En prensa. Prehistoria del Período Formativo en la cuenca alta del río Salado (Región del Loa Superior): Un estado de la cuestión. En Actas del XV Congreso Nacional de Arqueología Chilena, Arica, 2000.

STRUBE, L., 1926. Arte rupestre en Sudamérica, con especial descripción de los petroglifos de la provincia de Coquimbo, Chile. Texto mecanografiado, Concepción.

UHLE, M., 1922. Fundamentos étnicos y arqueología de Arica y Tacna. Boletín Ecuatoriano de Estudios Históricos. Universidad Central, Quito. 